\title{
The Estimation of Hydraulic Properties from Geophysical Measurement of Subsoil Depend on Regression Equation
}

\author{
Safaa F. Yasir ${ }^{1}$, Janmaizatulriah Jani ${ }^{1}$ \& Mazidah Mukri ${ }^{1}$ \\ ${ }^{1}$ Faculty of Civil Engineering, Universiti Teknologi Mara, UiTM, Shah Alam, 40450, Malaysia \\ Correspondence: Safaa F. Yasir, Faculty of Civil Engineering, Universiti Teknologi Mara, UiTM, Shah Alam, \\ 40450, Malaysia. E-mail: safaafaker@gmail.com
}

Received: March 22, 2019

Accepted: May 1, 2019

Online Published: May 23, 2019

doi:10.5539/mas.v13n6p12

URL: https://doi.org/10.5539/mas.v13n6p12

\begin{abstract}
This paper illustrated an establishment relationship between electrical resistivity by using electrical resistivity imaging (ERI) technique and hydraulic conductivity. The test conducted in two locations (Kampung Semerbok, Rembau and Felda Bukit Rokan Utara, Gemencheh) in Malaysia. Schlumberger array configuration was adopted by using ABEM SAS 4000 with eighty-one (81) electrodes for first site and forty-one (14) electrodes for second site. The total length of resistivity survey line was $400 \mathrm{~m}$ and $200 \mathrm{~m}$ for site one and two respectively. Statistical analysis based on regression equation was involved to find the relationship between hydraulic conductivity and resistivity. This result was compared with the hydraulic conductivity obtained from pumping tests for the well which is located within the resistivity survey line range. This study showed a good relationship between resistivity and hydraulic conductivity and can be used as preliminary tool to assess subsurface zone with non- invasive nondestructive for the soil with reducing time and cost.
\end{abstract}

Keywords: electrical resistivity imaging, regression equation, hydraulic conductivity

\section{Introduction}

Groundwater is found inside tanks in the ground (which is a rocky or sedimentary layer capable of contain a quantity of water and consist of non-consolidated materials such as sand, gravel or compact rocks such as stone (Sanding or limestone) or in the voids and cracks between soil granules. Geophysical methods have the advantage of providing information on the nature of soil and rocks between the well's locations. Therefore, the direct and indirect techniques (i.e. drilling of wells, on-site inspection and information geophysics) useful to detect the better location especially in areas where caves or cracks may be present (Perdomo, Ainchil, \& Kruse, 2014). In the last four decades the method of electrical resistance has been used intensive in situ investigation to address these methods to give a clear picture of nature, thickness and quality the hardness of the layers, the different depths as well as the detection of gaps and cracks below the surface and depth of water. Thus, the use of these methods reduces the number of wells to be dug or the tests to be performed (Lau, 2000). In hydrological studies, aquifer properties commonly involve Direct screening methods which is soil sampling, drilling tube well, pumping test and laboratory experiment. On-site investigation (e.g., drilling of wells, trenches and examination of models) provide information specific at the point or location where the excavation or inspection took place. Subsurface geology between those points may contain gaps or cracks or a significant physiological change in the nature of the soil which cannot interpreting by direct methods. Usually during the site investigation works, soil sampling will obtaining under either undisturbed or disturb condition (Haught \& Meerveld, 2011). Those classical soil identification processes may face limitation due to the cost and time particularly when it deals with large and difficult construction area. Moreover, conventional site investigation tools such as drilling methods experience difficulties in steep and hilly terrain, swampy areas, coastal regions and complex geomaterials areas which need to be investigated (Khatri, Shrivastava, \& Chandak, 2011).

According to (Antoly \& Larisa, 2002), high number of soil sampling was required in order to achieve high accuracy of soil properties assessment also clarified it is tending to achieve by conventional and it is time consuming and costly (Siddiqui \& Osman, 2012). At the turn of the century, many developments of drilling tools and other effort have been made to study groundwater. Before drilling tube well, must have an idea of reservoir characteristics and the quantity of aquifer. Suitable location should be identified in order to estimate potential aquifer (Gastélum, Sheng, \& Michelsen, 2012). The technique of electrical resistance is useful, efficient and economical way to 
determine the presence of groundwater. The electrical resistivity method can be used in a wide range of geophysical investigations, such as geothermal studies, exploration for minerals, archaeological surveys, geological mapping, and engineering site investigation. Geophysicists have also used it to determine the thickness of clay aquitards, bedrock, the vertical extent of certain types of soil saltwater intrusion, and the spread of groundwater contamination (Anomohanran, 2015).

The method of measuring electrical resistance is considered one of the important geophysical methods are used to designate the positions and volumes of the subsurface cavities because of the variation in the value of the resistance between the gaps and the surrounding rocks. Generally, the gaps are of high-quality electrical resistance in comparison to the surrounding rocks, due to the poor electrical connection of these gaps. This method is based on electrifying the electric current into the ground by two electrodes and then measuring voltage difference by another two electrodes. Therefore, any subsurface changes in the electrical conductivity (qualitative resistance) will change the flow of electric current lines, which in turn affects the distribution of the voltage within earth. Thus, the nature and distribution of rock layers under the surface can be identified by measuring the voltage electroplating on the earth's surface. Electrical resistivity test will lead to minimizing the amount of tube well by predict the aquifer locations which is important for optimized tube well site selection, thus will decrease the test pumping method cost substantially (Ariyo \& Adeyemi, 2009), (Sajeena, Abdul Hakkim, \& Kurien, 2014), (Hussain, Ullah, Akhter, $\&$ Aslam, 2017). The main purposed of geophysical method in this study is to find the hydrogeological properties based on regression equation. This study adopted regression equation to find the hydraulic conductivity from electrical resistivity imaging. Table 1 shows the standard values of hydraulic conductivity.

Table 1. Bouwer's standard for hydraulic conductivity (Bouwer, 1978).

\begin{tabular}{ll}
\hline Permeability K (m/day) range & Material \\
\hline Unconsolidated deposits & \\
$10-8-10-2$ & Deep clay beds. \\
$0.001-0.1$ & Clay, sand and gravel mixtures (till) \\
$0.01-0.2$ & Clay soils (surface) \\
$0.1-1$ & Loamy soils (surface) \\
$1-5$ & Fine grained sand \\
$5-20$ & Medium grained sand \\
$5-100$ & Sand and gravel mixtures \\
$20-100$ & Coarse grained sand \\
$100-1000$ & Gravel \\
Hard rocks & \\
30 & Chalk \\
3.1 & Sandstone \\
0.94 & Limestone \\
0.001 & Dolomite \\
1.4 & Granite, weathered \\
0.2 & schist \\
\hline
\end{tabular}

\section{Method}

To accomplish the objectives of this study, statistical analytical and filed work was conducted in this study. A two line of field 2-D electrical resistivity imaging was conducted using ABEM SAS 4000 equipment at Kampung Semerbok, Rembau and Felda Bukit Rokan Utara, Gemencheh Malaysia (Figure 1). These sites were considered suitable for this study because tube well exist and pumping tests data available too so the hydraulic conductivity which is computing from Electrical Resistivity Imaging can easily compare with the hydraulic conductivity that calculating from the pumping test (drawdown test, recovery test and constant discharge test). The General Department of Geoscience Malaysia (JMG) conducted the tube well drilling in Kampung Semerbok, Rembau and 
Felda Bukit Rokan Utara, Gemencheh as shown in Figure 2 and Figure 3. The drilling depth was until 100m for the first site and $72 \mathrm{~m}$ for second site. For Rembau site, the borehole log showed two layers reddish clay with thickness $12 \mathrm{~m}$ while the second layer was schist until $100 \mathrm{~m}$ depth. The borehole log for the second location showed three layers of subsoil which is brownish yellow with silty sand until $12 \mathrm{~m}$ depth, dark grey weak graphitic shale with quartz veins until $62 \mathrm{~m}$ from ground level and dark grey carbonaceous schist with some quartz fragment until depth $72 \mathrm{~m}$.

Schlumberger configurations was used with eighty-one (81) numbers of electrode and four (4) resistivity land cables each one is $100 \mathrm{~m}$ for the first location while half these electrodes and land cables was used for the second location. The coordinate of the resistivity survey line can found at (Yasir, Jani, \& Mukri, 2019). The electrode was connected to resistivity land cables using jumper cable. The total line of electrical resistivity survey line was 400 meters for Kampung Semerbok, Rembau site and 200 meters for Felda Bukit Rokan Utara, Gemencheh site. As reported by (Khatri et al., 2011),(Godio, Strobbia, \& De Bacco, 2006) and (Cosenza et al., 2006), even though the individual standard performance for the geophysical methods is based on the limitations of the physical fundamental (signal to-noise ratio, penetration and resolution), geophysical methods still have advantages to performed fast and low cost with ability to survey more larger areas (Mauritsch et al., 2000).

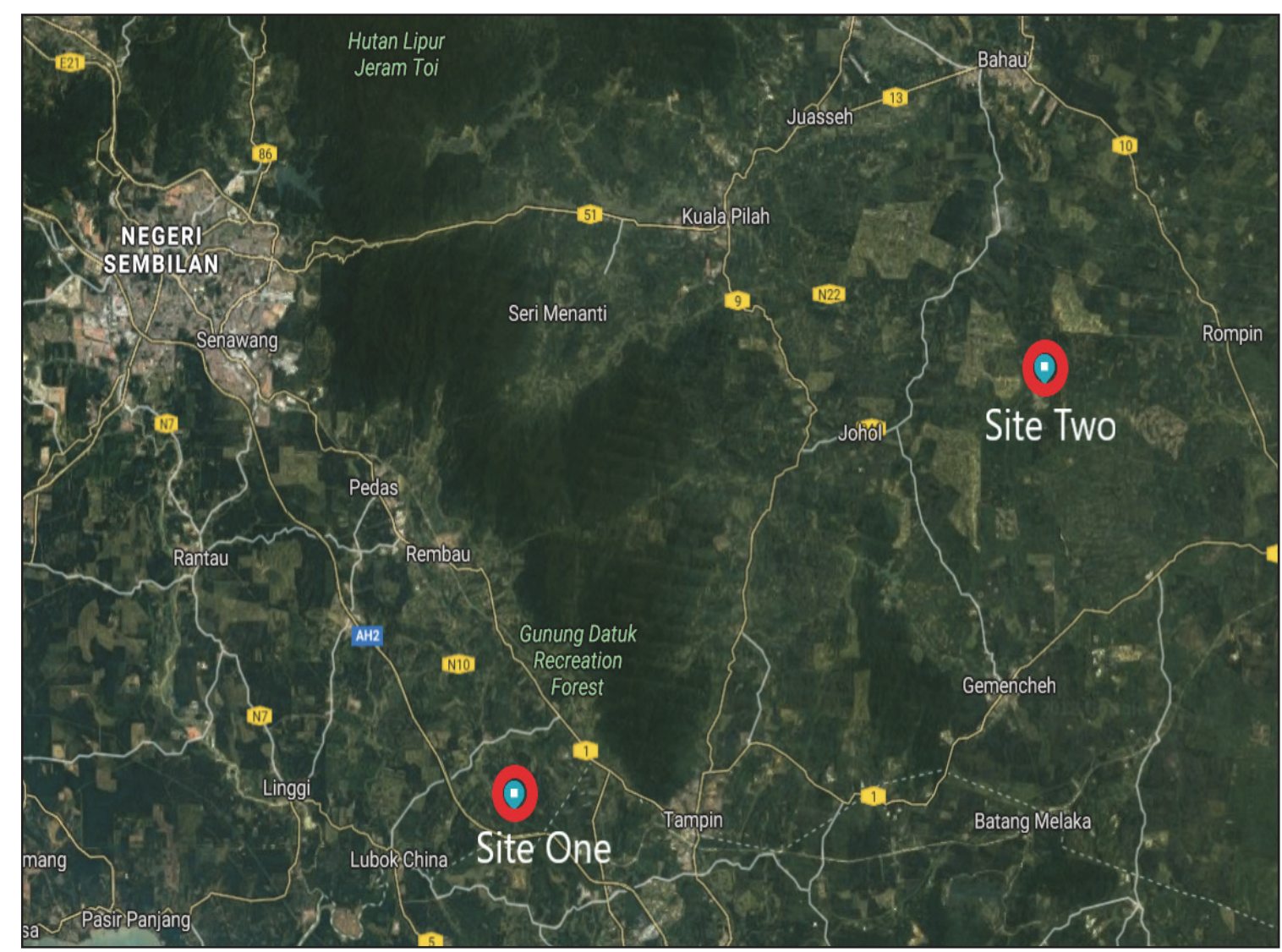

Figure 1. Site one and two of 2-D electrical resistivity imaging method in Malaysia. 


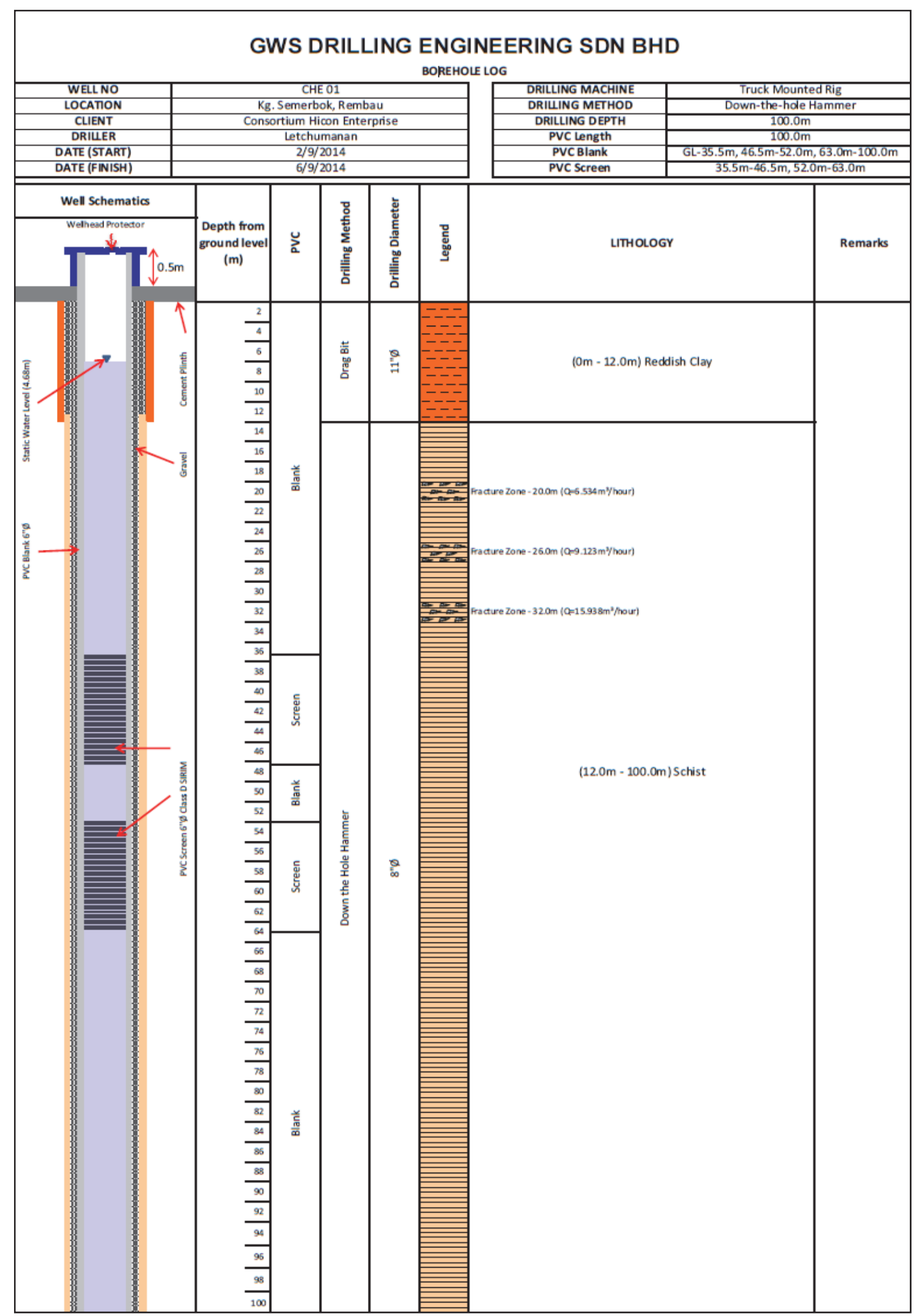

Figure 2. Borehole Log Kampung Semerbok, Rembau 


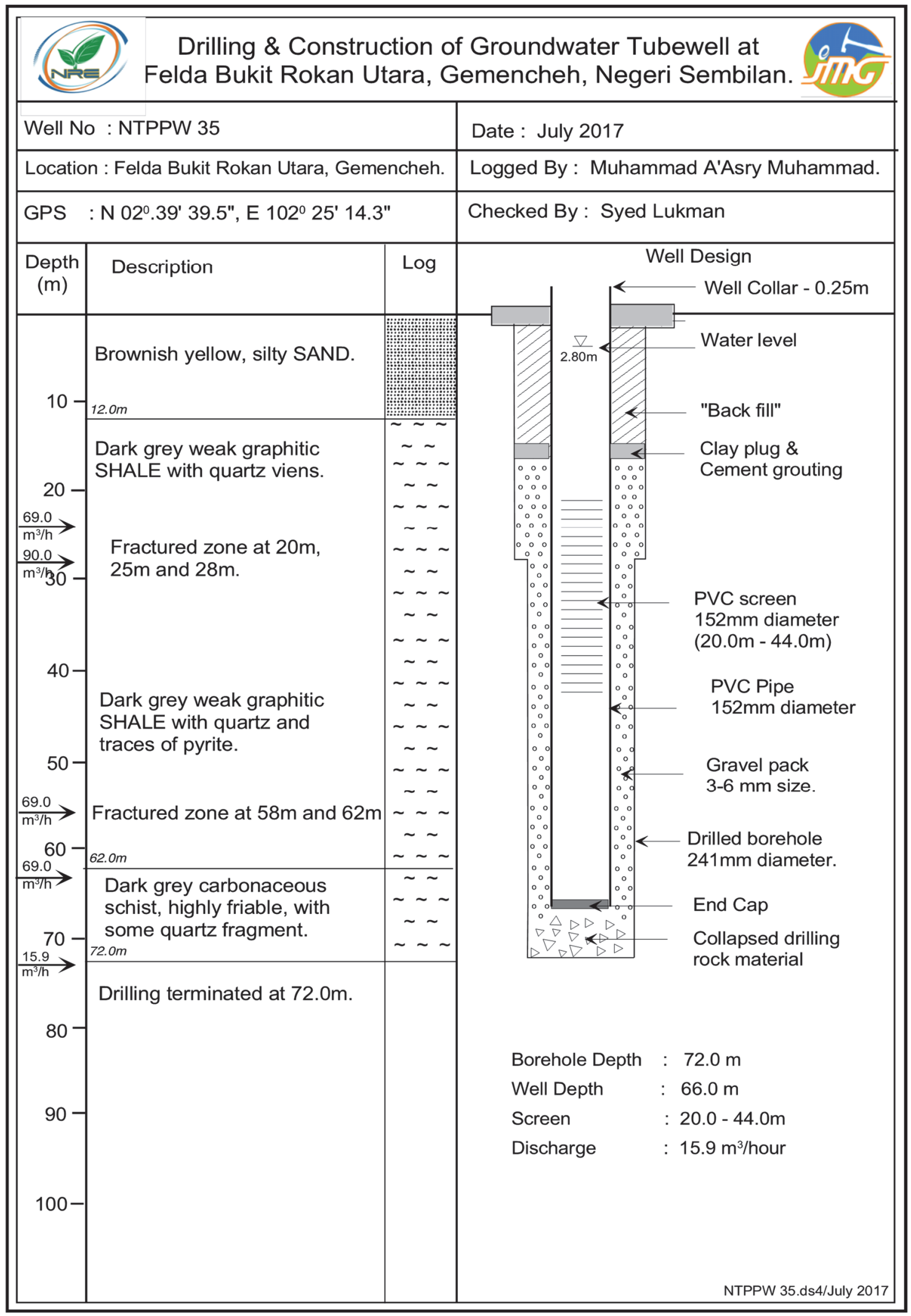

Figure 3. Borehole Log Felda Bukit Rokan Utara, Gemencheh 


\section{Data Processing}

The Terrameter SAS 4000 data logger devise is automatically saved the raw data from survey line of 2D electrical resistivity imaging. The raw data was saved at the computer for processing. By using smooth constraint least square method, a smooth boundary produced for good understanding to the subsurface. (Abidin, Saad, Ahmad, Wijeyesekera, \& Baharuddin, 2014) mentions that this method is more suitable than a robust method for subsurface in contrast with fractured material which is sharp geomaterials boundary. The resistivity data was interpreted with RES2DINV program which is a computer software which is automatically determine a two-dimensional (2D) resistivity model for the subsurface for the data obtained. The inverse model resistivity sections are shown in Figure 4 (Site one) and Figure 5 (line two).

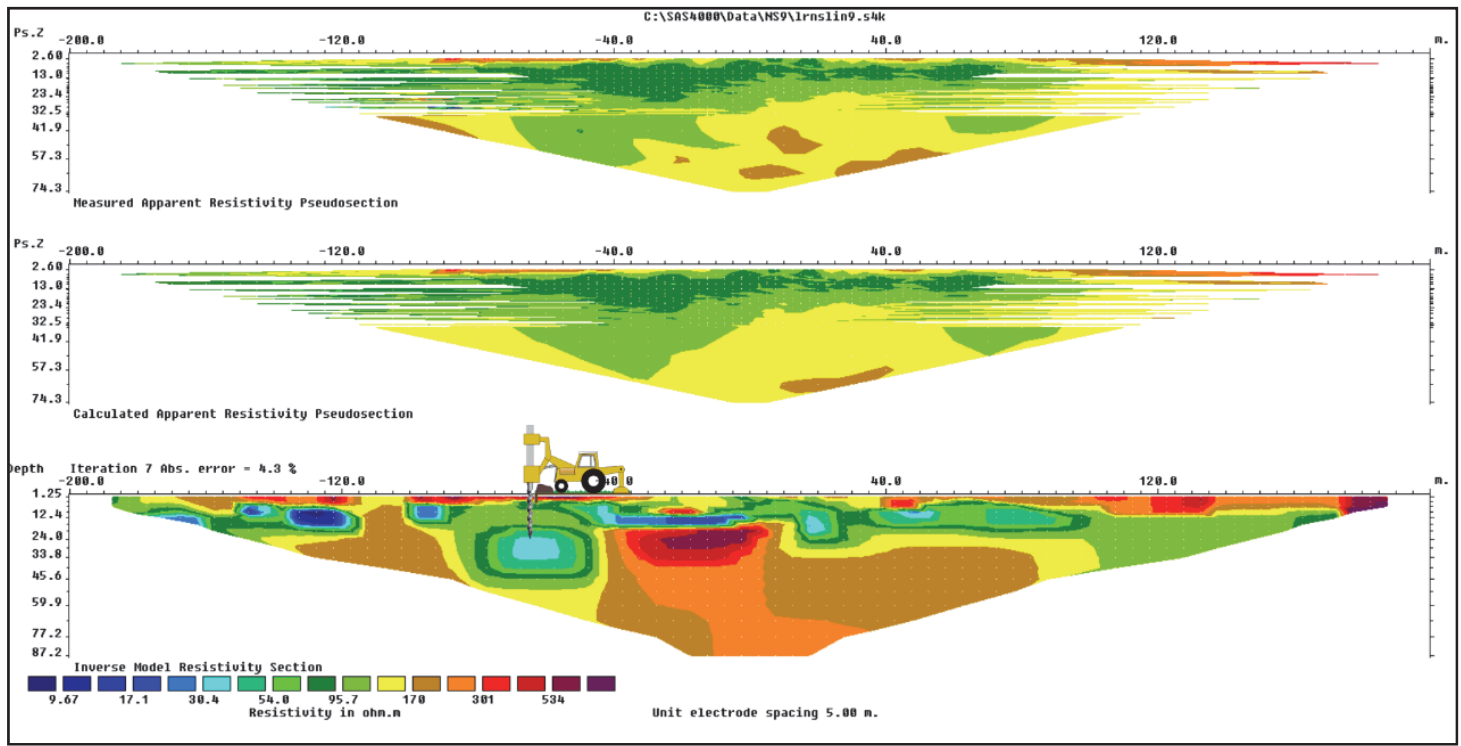

Figure 4. Resistivity image of Kampung Semerbok, Rembau

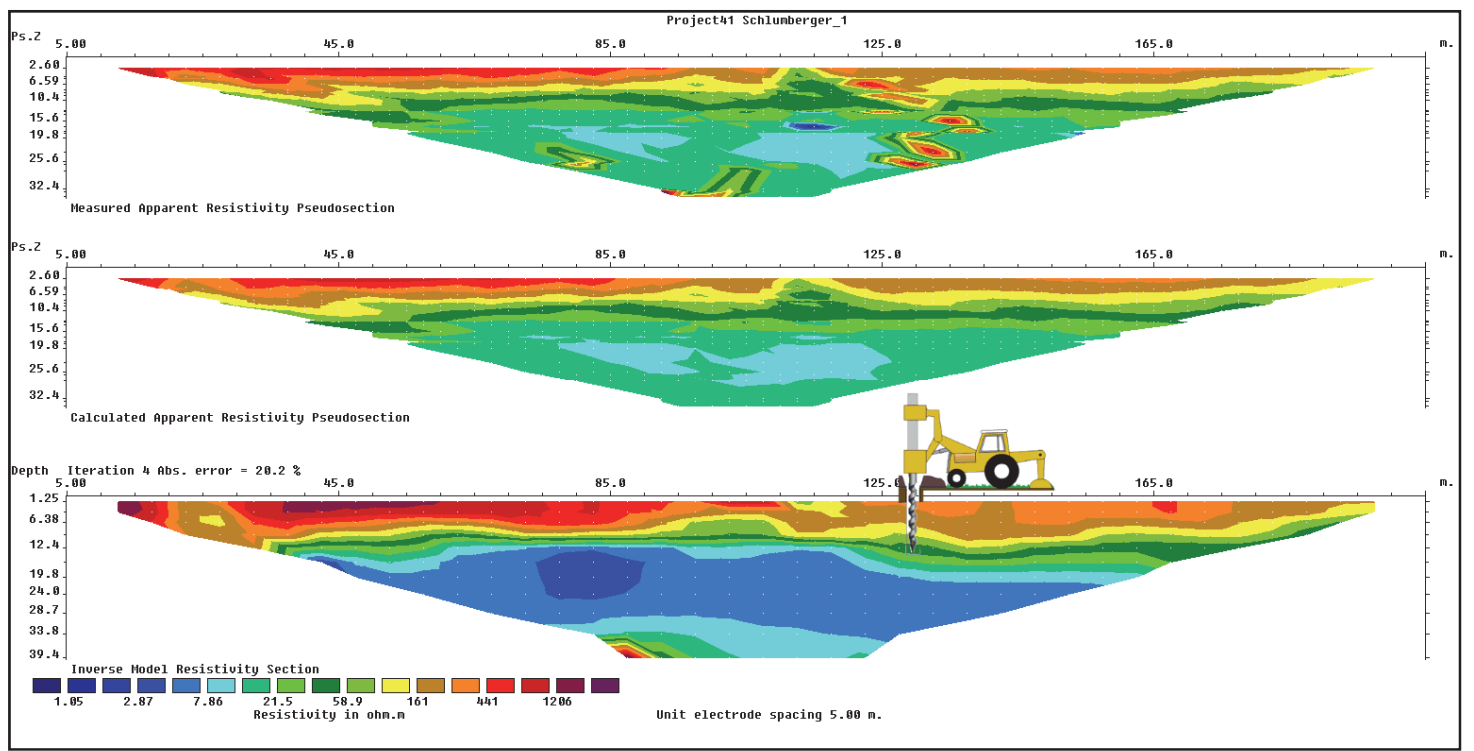

Figure 5. Resistivity image of Felda Bukit Rokan Utara, Gemencheh.

\section{Analytical Calculations Using Regression Equation}

By using RES2DINV Software, the raw data of resistivity was converted and saved to (XYZ) format to find the value of resistivity for each layer from the profile of the depth. The K-value was assumed depend on Bouwer's standard of hydraulic conductivity (Bouwer, 1978). Regression analysis is a statistical method used to formulate a mathematical equation in which the effect of one variable can be measured on the other where the purpose of using the simple linear regression method is to study and analysis the effect of a quantitative variable (hydraulic 
conductivity K regression) on another quantitative variable (resistivity ) (Zou, Tuncali, \& Silverman, 2003). Regression equation is:

$$
\bar{y}=a+b X
$$

Where Regression Coefficient is

$$
b=\frac{n \sum X Y-\sum(X) \sum(Y)}{n \sum X^{2}-\left(\sum X\right)^{2}}
$$

Gradient constant (fraction of the vertical axis $\mathrm{Y}$ ) is

$$
a=\frac{\sum Y-b \sum X}{n}
$$

Where: $\mathrm{X}=(\Omega)$ Resistivity in (Ohm-m).

$\mathrm{Y}=(\mathrm{K}$-value $)$ Assumed hydraulic conductivity.

$\bar{y}_{=}(\mathrm{K}$ regression $)$ Hydraulic conductivity calculated from regression equation, and $\mathrm{n}=$ variable's data number.

\section{Tube Well Analyzing}

In order to determine the most suitable location for drilling any well, several factors should be taken into consideration, the most important of which are geology, geomorphology and hydrological nature. Hydraulic conductivity is one of the most important parameters of hydrological science which is used in all equations for groundwater flow. By using continuity equation and Darcy's law, K-value was calculated from pumping tests (drawdown, recovery, constant discharge) (Yasir, Jani, \& Mukri, 2018).

$$
\begin{array}{r}
\mathrm{Q}=\mathrm{V}^{*} \mathrm{~A} \\
V=\frac{\Delta h}{Q * T} \\
K=\frac{Q * \Delta h}{A * \Delta{ }^{*}}
\end{array}
$$

Where: $\mathrm{Q}=$ Flow rate of pumping, $\mathrm{V}=$ The velocity of fluid, $\mathrm{A}=$ Area, ${ }^{\Delta h}=$ The drawdown, $\mathrm{T}=$ Time, $\mathrm{L}=$ Length.

\section{Results}

From Equation (5) the velocity was calculated from the drawdown test based on continuity equation. The area (A) and Hydraulic conductivity (K) was calculated from Equation (4) and Equation (6) respectively. Figure 6 show the relationship between electrical Resistivity topography (imaging) and K-value (hydraulic conductivity) for Kampung Semerbok, Rembau site where the R2 $=0.6$ polynomial from second degree. K field in Figure 7, Figure 8 and Figure 9 represent the hydraulic conductivity from Step- drawdown test, Recovery Test and Constant Discharge Test respectively while K Regression represent the Hydraulic conductivity calculated from electrical resistivity imaging for first site.

Figure 10 show the relationship between electrical Resistivity imaging and K-value (hydraulic conductivity) for Felda Bukit Rokan Utara, Gemencheh site where the R2 $=0.947$ and the equation was exponential. K field in Figure 11, Figure 12 and Figure 13 represent the hydraulic conductivity from Step- drawdown test, Recovery Test and Constant Discharge Test respectively while K Regression represent the Hydraulic conductivity calculated from electrical resistivity imaging for second site. 


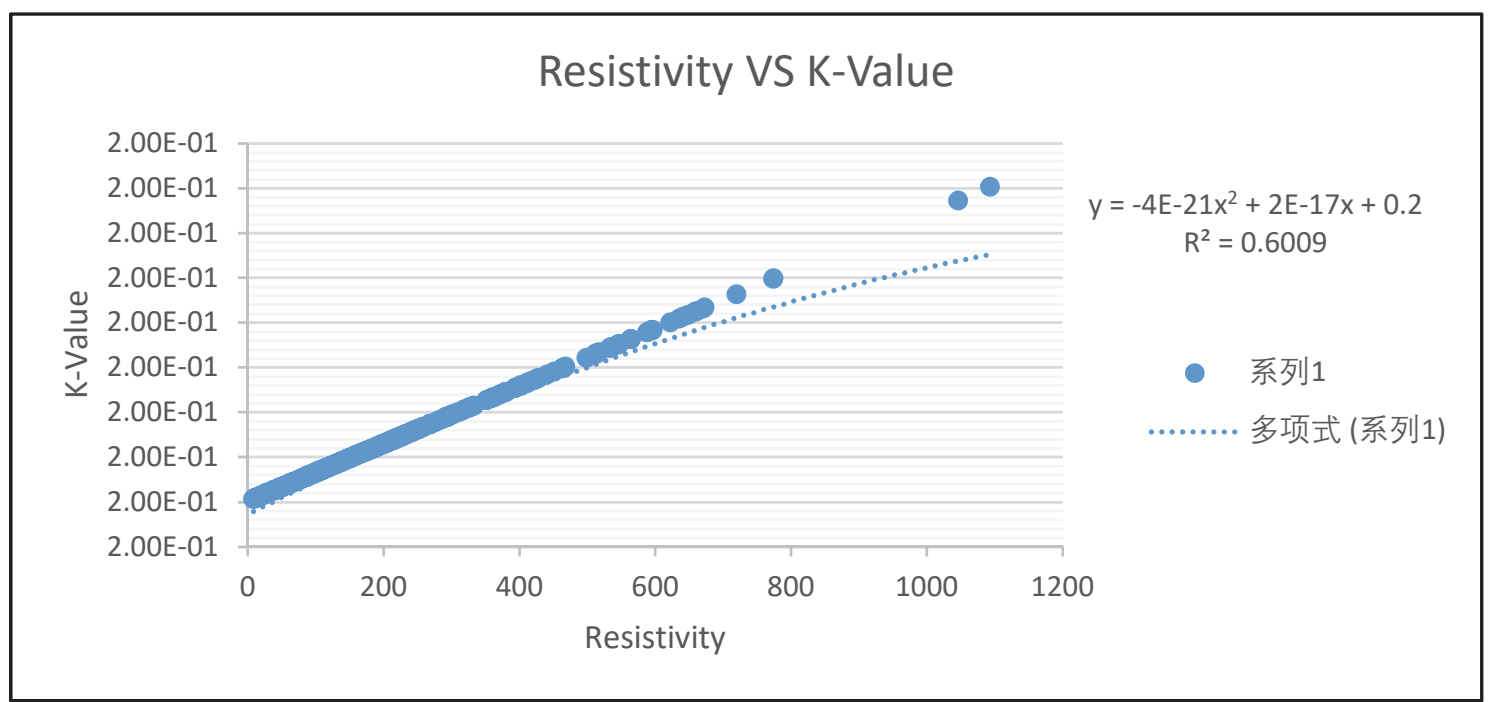

Figure 6. Resistivity versus K-value for Kampung Semerbok, Rembau.

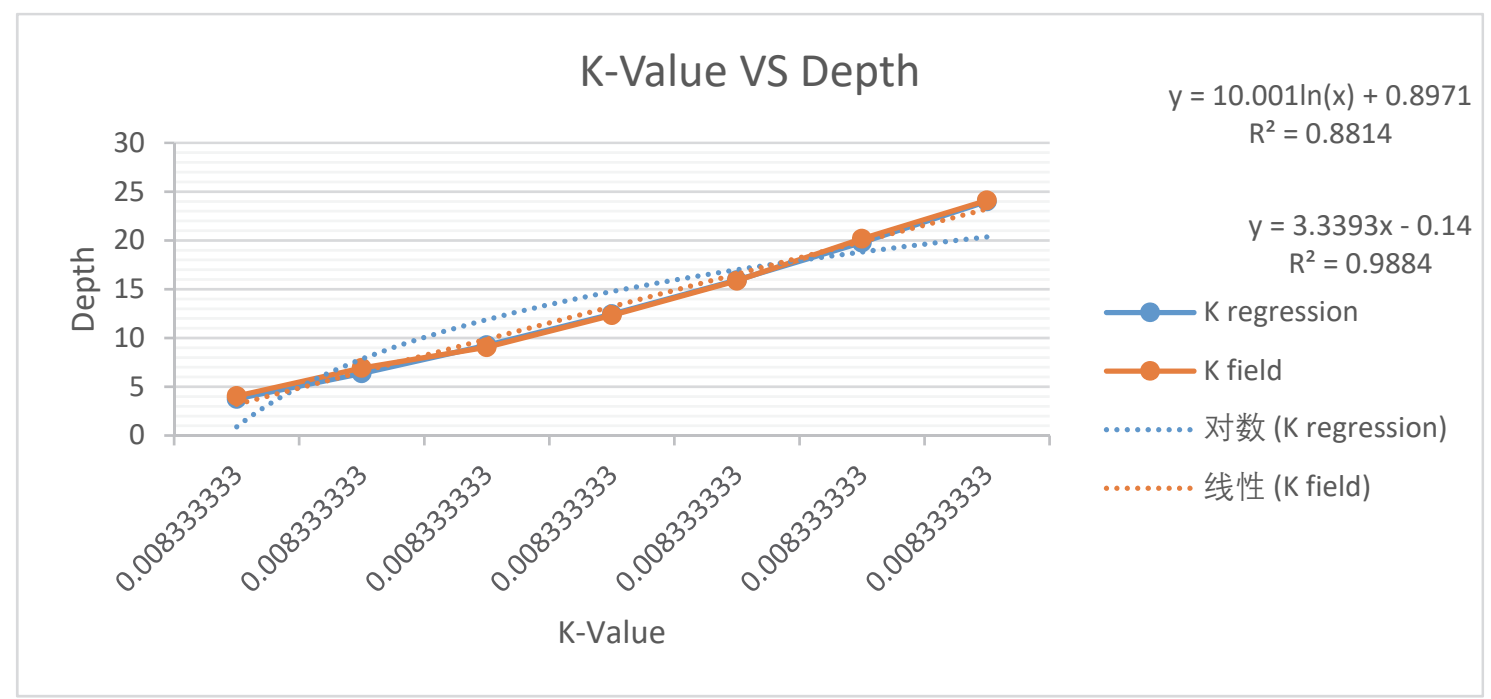

Figure 7. Hydraulic conductivity from Step- drawdown test and Regression Equation

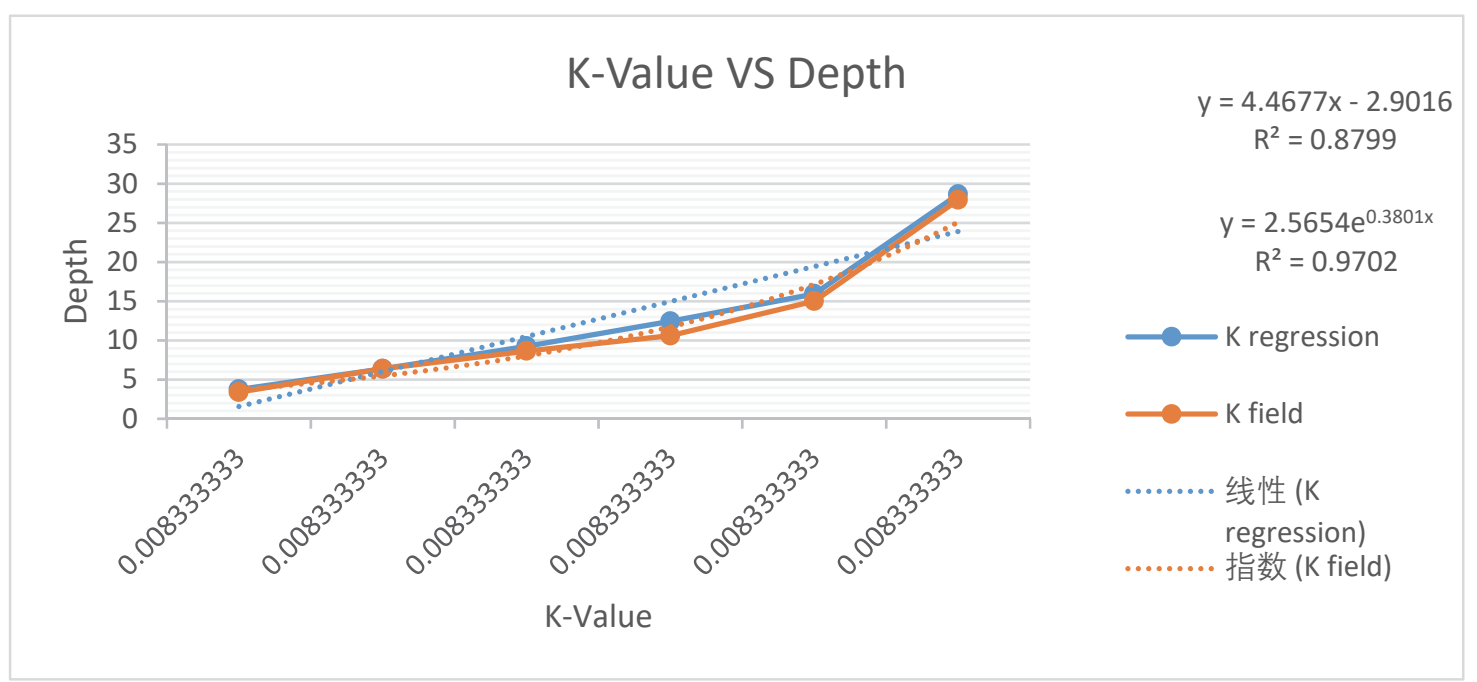

Figure 8. Hydraulic conductivity from Recovery Test and Regression Equation 


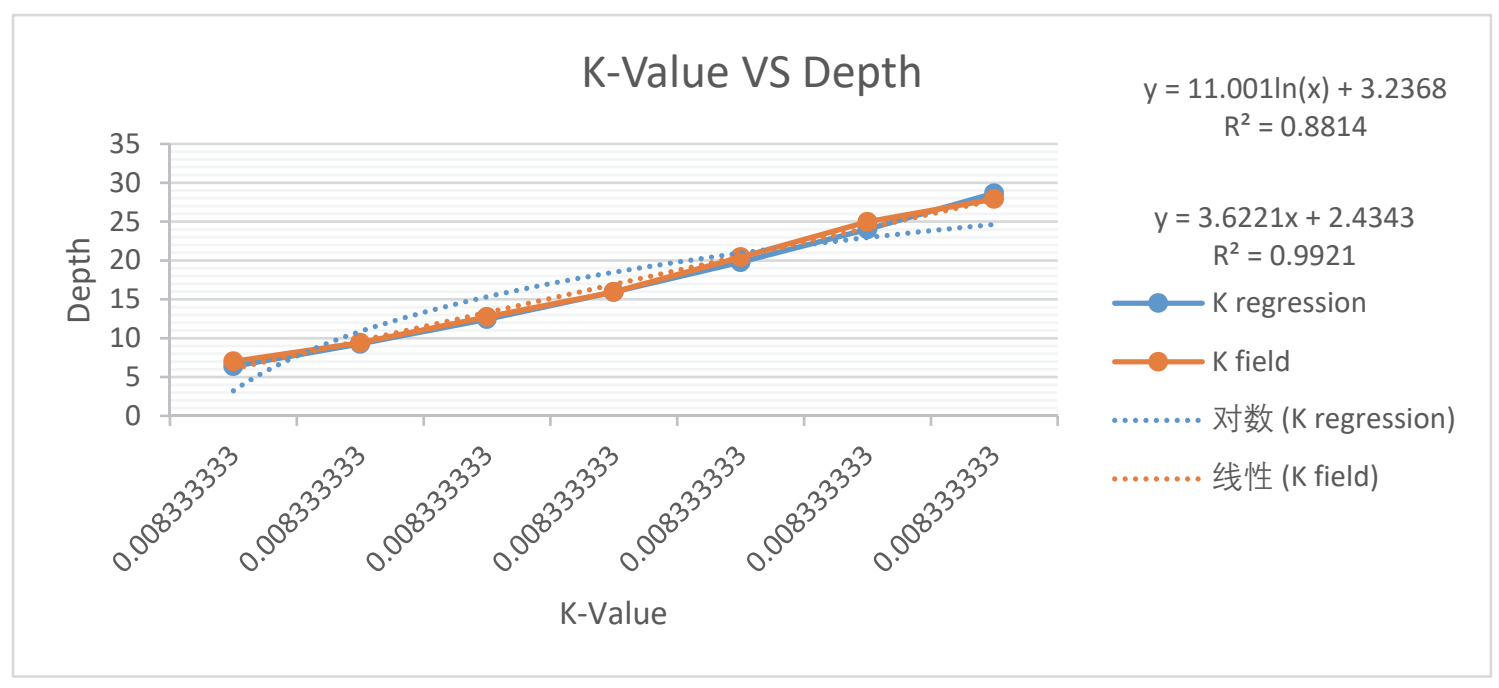

Figure 9. Hydraulic conductivity from Constant Discharge Test and Regression Equation

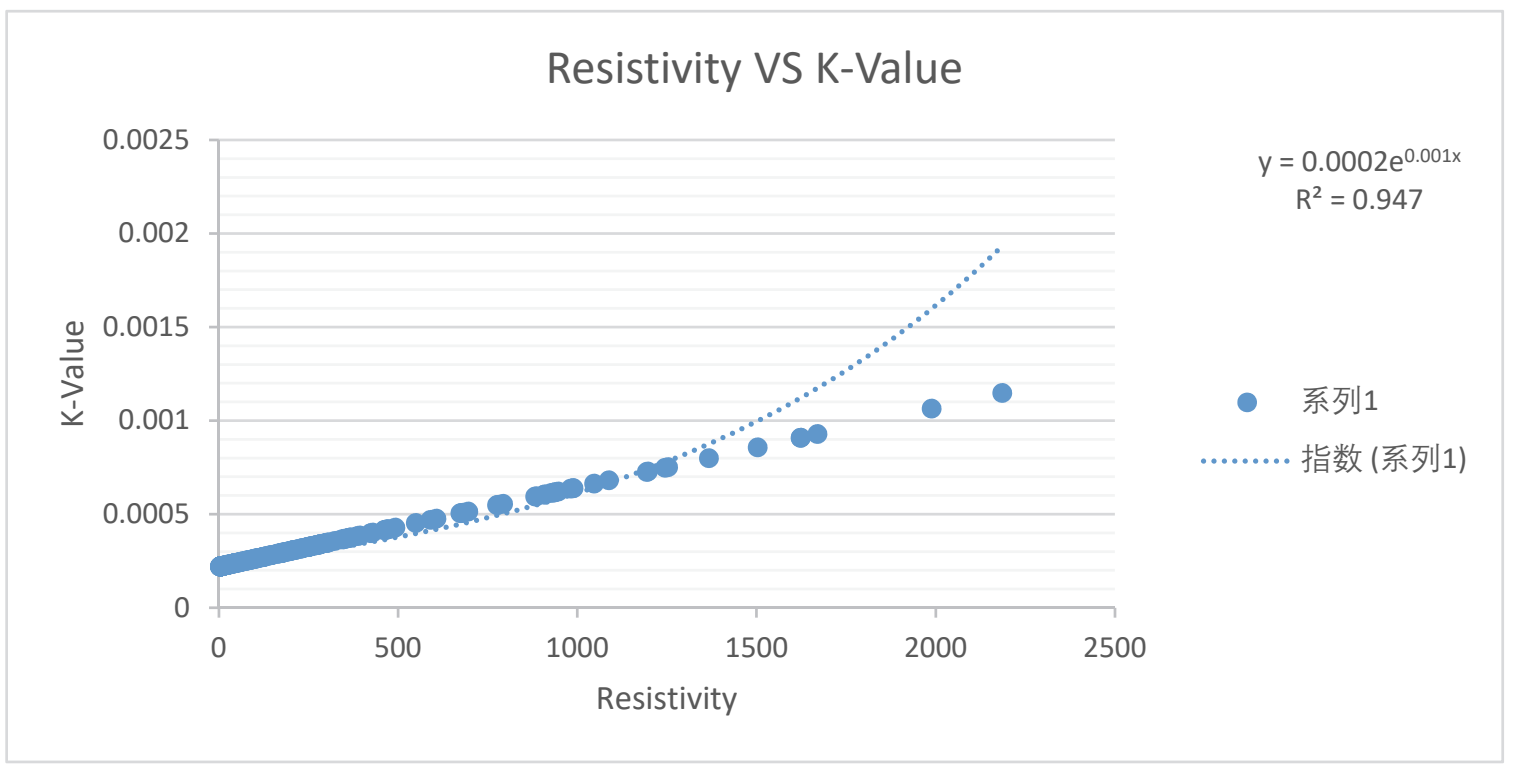

Figure 10. Resistivity versus K-value Felda Bukit Rokan Utara, Gemencheh 


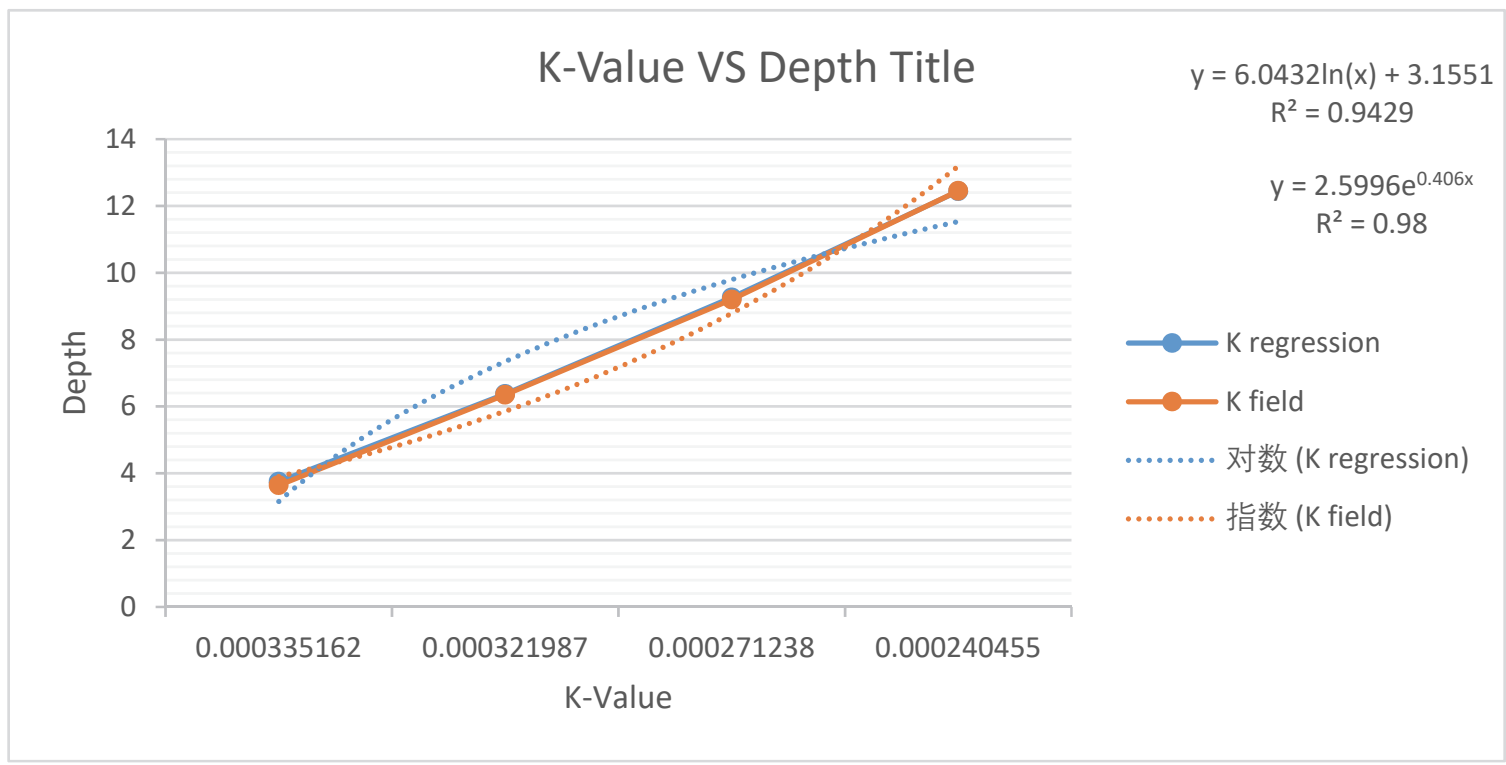

Figure 11. Hydraulic conductivity from Step- drawdown test and Regression Equation

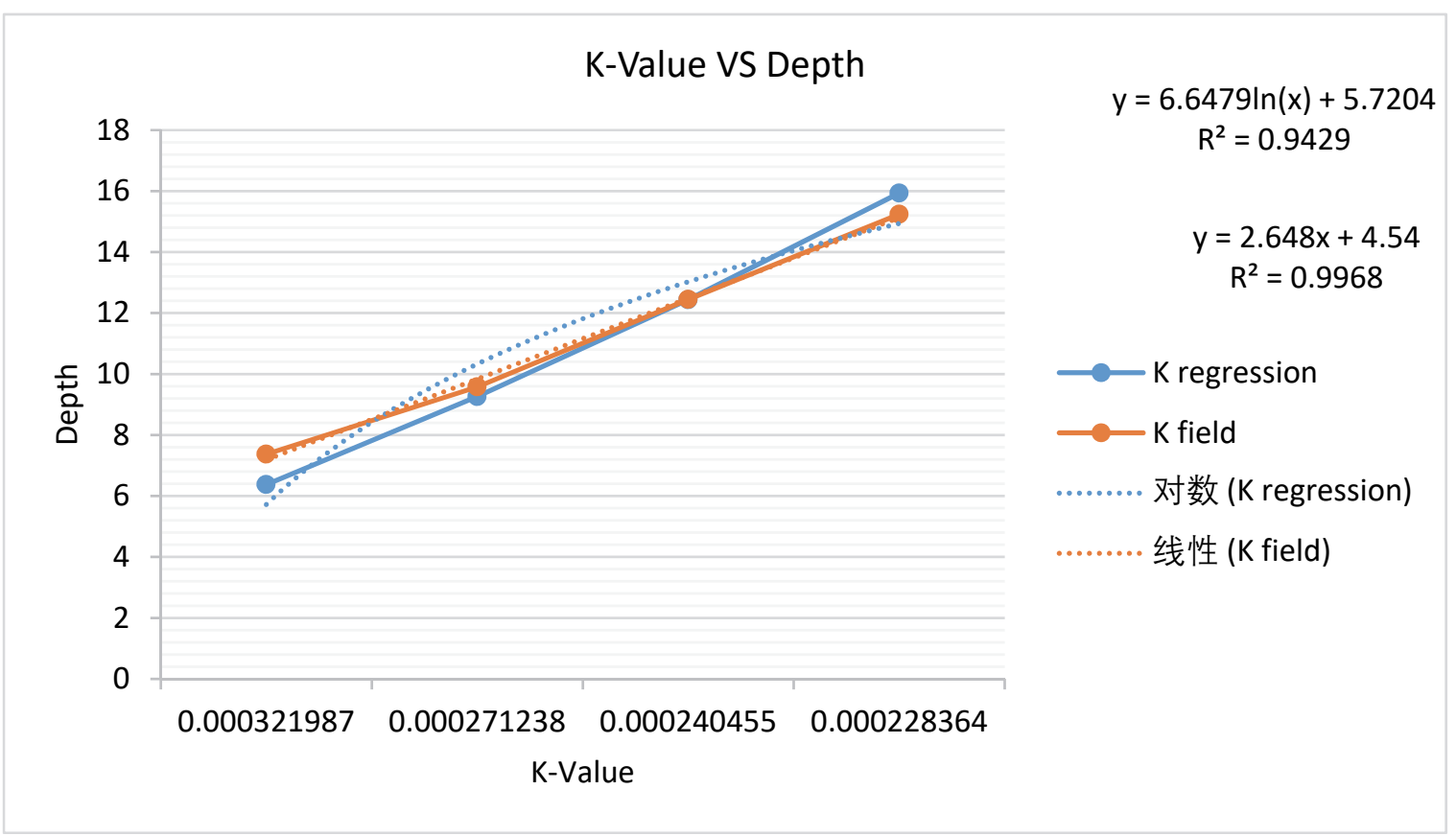

Figure 12. Hydraulic conductivity from Recovery Test and Regression Equation 


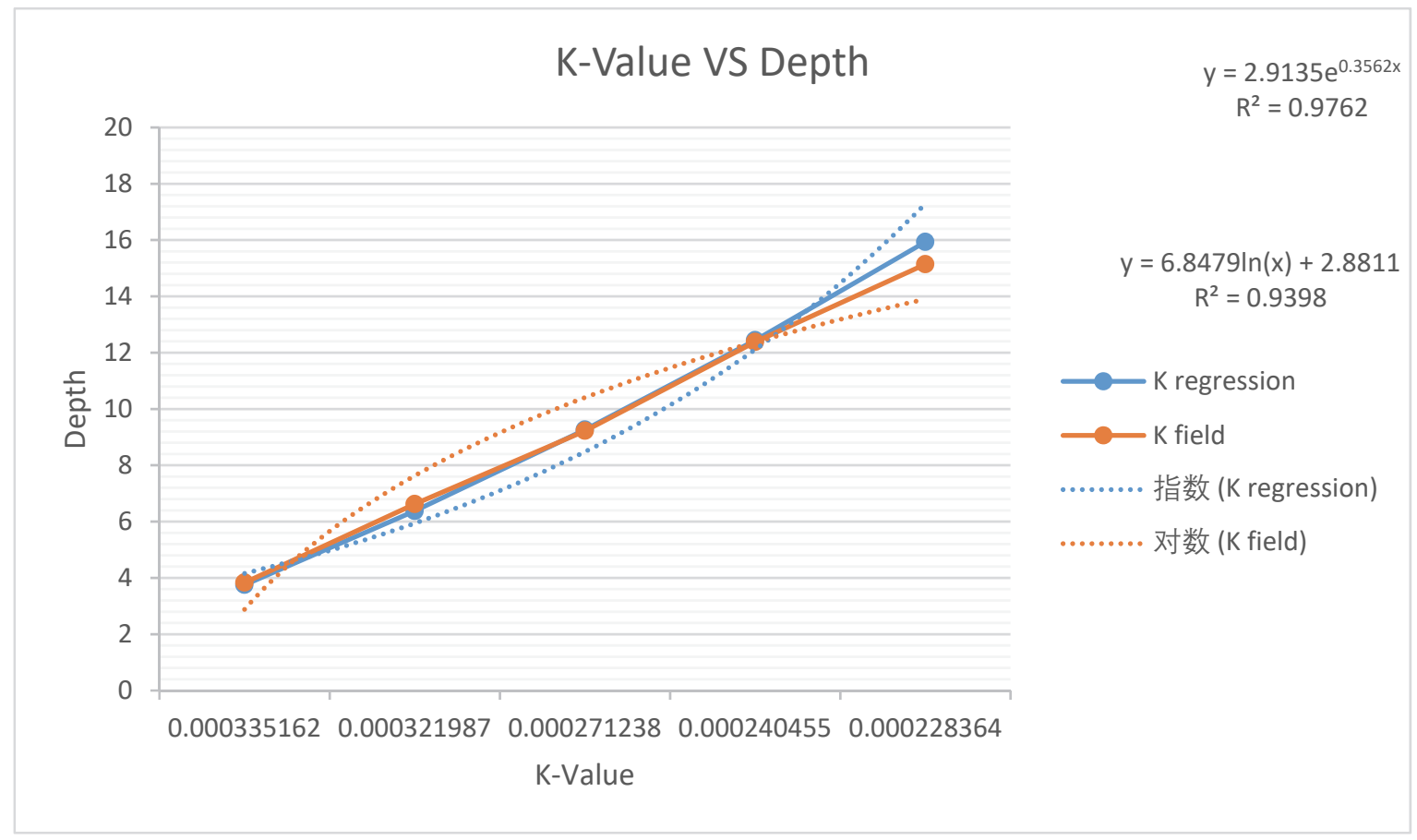

Figure 13. Hydraulic conductivity from Constant Discharge Test and Regression Equation

\section{Conclusions}

- The hydraulic conductivity $(\mathrm{K})$ and electrical resistivity $(\Omega)$ of an aquifer is highly influence by the nature of layer of aquifer. The regression equation was calculating depend on Equation (1) to Equation (3) and it was found to be: $\mathrm{K}=0.2+\left(1.28 \mathrm{E}-17^{*} \Omega\right)$ for the first site and $\mathrm{K}=3.6 \mathrm{E}-06+\left(7.07 \mathrm{E}-09^{*} \Omega\right)$ for the second site.

- The result of $\mathrm{K}$-value from regression equation was compatible with Table 1.

- $\quad$ From Figure 7, Figure 8 and Figure 9, the hydraulic conductivity (K-value) from this study (K Regression) was similar to (K-value) from field (Drawdown test), (Recovery Test) and (Constant Discharge Test) respectively.

- This study was successfully linked the hydraulic conductivity with electrical resistivity imaging by using statistical regression equation.

\section{References}

Abidin, M., Saad, R., Ahmad, F., Wijeyesekera, D., \& Baharuddin, M. (2014). Correlation analysis between field electrical resistivity value (ERV) and basic geotechnical properties (BGP). Soil Mechanics and Foundation Engineering, 51(3), 117-125. https://doi.org/10.1007/s11204-014-9264-x

Anomohanran, O. (2015). Hydrogeophysical and hydrogeological investigations of groundwater resources in Delta Central, Nigeria. Journal of Taibah University for Science, 9(1), 57-68. https://doi.org/10.1016/j.jtusci.2014.06.003

Antoly, P., \& Larisa, P. (2002). Electrical fields and soil properties. Paper presented at the 17. World congress of soil science, Bangkok (Thailand), 14-21 Aug 2002.

Ariyo, S. O., \& Adeyemi, G. O. (2009). Role of electrical resistivity method for groundwater exploration in hard rock areas: a case study from Fidiwo/Ajebo areas of Southwestern Nigeria. The Pacific Journal of Science and Technology, 10(1), 483-486.

Bouwer, H. (1978). Groundwater hydrology.

Cosenza, P., Marmet, E., Rejiba, F., Cui, Y. J., Tabbagh, A., \& Charlery, Y. (2006). Correlations between geotechnical and electrical data: A case study at Garchy in France. Journal of Applied Geophysics, 60(3-4), 165-178. https://doi.org/10.1016/j.jappgeo.2006.02.003

Gastélum, J., Sheng, Z., \& Michelsen, A. (2012). Understanding Surface Water and Groundwater Interactions in 
the Mesilla Basin. Paper presented at the World Environmental and Water Resources Congress 2012: Crossing Boundaries.

Godio, A., Strobbia, C., \& De Bacco, G. (2006). Geophysical characterisation of a rockslide in an alpine region. Engineering Geology, 83(1-3), 273-286. https://doi.org/10.1016/j.enggeo.2005.06.034

Haught, D., \& Meerveld, H. (2011). Spatial variation in transient water table responses: differences between an upper and lower hillslope zone. Hydrological Processes, 25(25), 3866-3877. https://doi.org/10.1002/hyp.8354

Hussain, Y., Ullah, S. F., Akhter, G., \& Aslam, A. Q. (2017). Groundwater quality evaluation by electrical resistivity method for optimized tubewell site selection in an ago-stressed Thal Doab Aquifer in Pakistan. Modeling Earth Systems and Environment, 3(1), 15. https://doi.org/10.1007/s40808-017-0282-3

Khatri, R., Shrivastava, V., \& Chandak, R. (2011). Correlation between vertical electric sounding and conventional methods of geotechnical site investigation Int. Journal of Advanced Engineering Sciences and Technologies, 4, 042-053.

Lau, K. (2000). A review of downhole geophysical methods for ground investigation: Geotechnical Engineering Office, Civil Engineering Department.

Mauritsch, H. J., Seiberl, W., Arndt, R., Römer, A., Schneiderbauer, K., \& Sendlhofer, G. P. (2000). Geophysical investigations of large landslides in the Carnic Region of southern Austria. Engineering Geology, 56(3-4), 373-388. https://doi.org/10.1016/S0013-7952(99)00120-9

Perdomo, S., Ainchil, J. E., \& Kruse, E. (2014). Hydraulic parameters estimation from well logging resistivity and geoelectrical measurements. Journal of Applied Geophysics, 105, 50-58. https://doi.org/10.1016/j.jappgeo.2014.02.020

Sajeena, S., Abdul Hakkim, V., \& Kurien, E. (2014). Identification of groundwater prospective zones using geoelectrical and electromagnetic surveys. Int. J. Eng. Invent, 3(6), 1.

Siddiqui, F. I., \& Osman, S. (2012). Integrating geo-electrical and geotechnical data for soil characterization. International Journal of Applied Physics and Mathematics, 2(2), 104.

Yasir, S. F., Jani, J., \& Mukri, M. (2018). GEOPHYSICAL MEASUREMENT FOR ESTIMATION OF GROUNDWATER HYDRAULIC PROPERTIES. Data in Brief. https://doi.org/10.1016/j.dib.2018.10.057

Yasir, S. F., Jani, J., \& Mukri, M. (2019). A dataset of visualization methods to assessing soil profile using RES2DINV and VOXLER software. Data in Brief, 103821. https://doi.org/10.1016/j.dib.2019.103821

Zou, K. H., Tuncali, K., \& Silverman, S. G. (2003). Correlation and simple linear regression. Radiology, 227(3), 617-628. https://doi.org/10.1148/radiol.2273011499

\section{Copyrights}

Copyright for this article is retained by the author(s), with first publication rights granted to the journal.

This is an open-access article distributed under the terms and conditions of the Creative Commons Attribution license (http://creativecommons.org/licenses/by/4.0/). 